68.

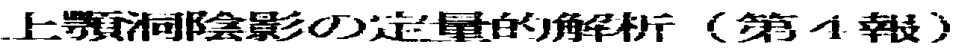

Quantitative Assessmennt of X-ray Opacity in the Maxillary Sinus

\title{
愛媛大学㫟学部咐属病院 放射線部
}

○田頭 裕之

Hiroyuki Tagasira
中田 茂

Sigeru Nakata
吉本. 政弘

Masahiro Yosimoto Tosiaki Kawakani
【目的】今回我々は、第3 報に引き続き上頻河陰影の定量的解析考 実際の臨床例を用いて行い、診断領域での有用性を模討した。

【方法】定量值の測定方法は左右眼简無名線と眼简の交点を結ぶ直 線上に眼䆟下孔から开楾を引き、交点を中心に $8 \times 8$ ビクセルの

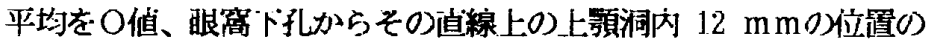

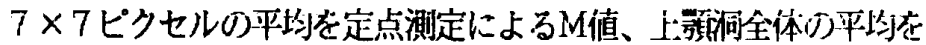
総平均M値とした。

眥院耳鼻科を受診した通去2年間の約1000名の資料の中から、慢性 副鼻腔炎疑いにて撮影した小兄、成人合わせて144名 288例定定量

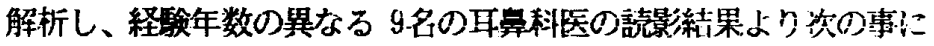
ついて調くた。

(1) 耳鼻科医の経㻌年数の違いによる診斩のバジキ。

(2) 定量值の䋠证のための) 1 方法 (M-O值とM／O值の比較）。

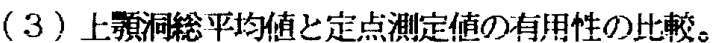

(4) 各々の読影結果のスペアマンの順位相関俰数を求め、最も相 関のよい武料からスルミノフの尧却検定を:用いて定量值々読 影基準の関係在求める。

【結果】1.9名の聛科医の䛃㟜結果のバラッキは予想以上に大 きく、定量化の)必要性を再確認した。

2. 大人の判定基準 1 と 5 の上敄洞平均によら $\mathrm{M} / \mathrm{O}$ 值と $\mathrm{M}-\mathrm{O}$ 值 を $\mathrm{fig} 1$ に示す。判定 1 と 5 平均值の空でそれぞれの摽隼偏差

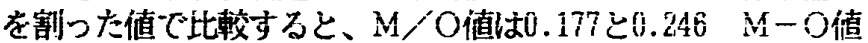
は 0.244 と 0.480 であり、M/O值の方㘳分類に逼している。

3. 子供の判定基隼 1 と50定量値をFig 2に示す。同㥞に比較す ると、 $\mathrm{M} / \mathrm{O}$ 值は $0.25 と 0.377 \mathrm{M}-\mathrm{O}$ 值出 0.305 こ0.525 で ありこれもM/O值の方》分類に墥している。

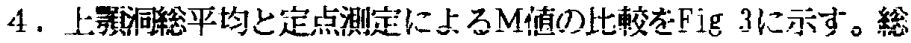
平均に比べ定点値は判定 10 定量値が 0.1 近く小さく、判定

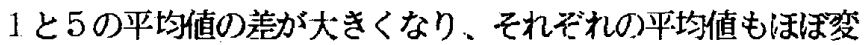
化なし。従って定点潰によるM値の方が適していると考える。

5.9名の判定結果からスペアマンの順位相關伱数を求め、最も相 関の良かった目逶科矤の 288側の読影結果を基にスルミノプ

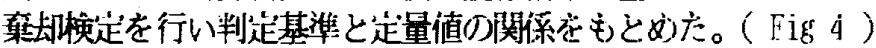
検定前に比べ刵定基准 1 と 2 2 と 3 の間の平均值の 差が大きくなり、判定基準 1 と3で梅準偏差汃令さく なり好結果を得充。

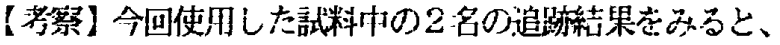
9 名全てが判定基隼 1 と回答した症例D中に判定基淮 20 場合がをり、耳當科医の肉腿による読影も限界と考える。 今後定量解析に上る情垠提供が、初期診断に於て重要であ ると考える。定量値の標焦焦差ついては、統計学处理をす るにはデー夕数が少ない事が1つの原因であり、また耳基 科医の読影のバラツキも原因と考える。これからも更に研 究を進ぬ、標淮偏差を小さくし信頼性の高い支擐馀断が出 来るよう努力したい。

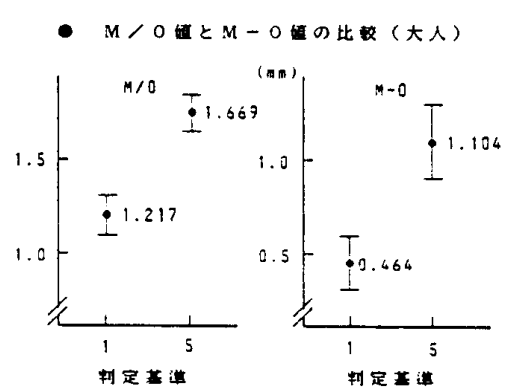

Fig 1

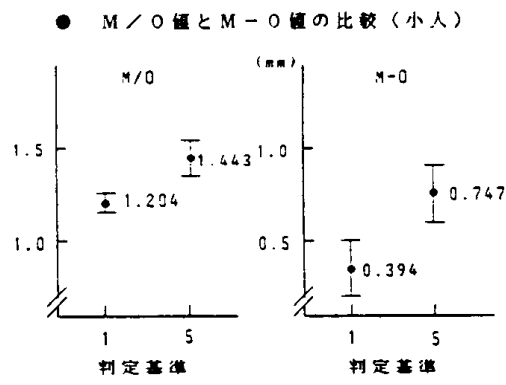

Fig 2

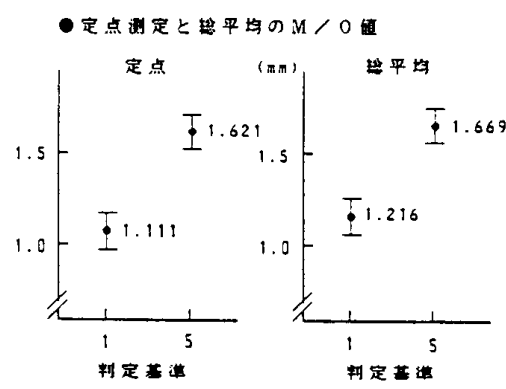

Fig 3

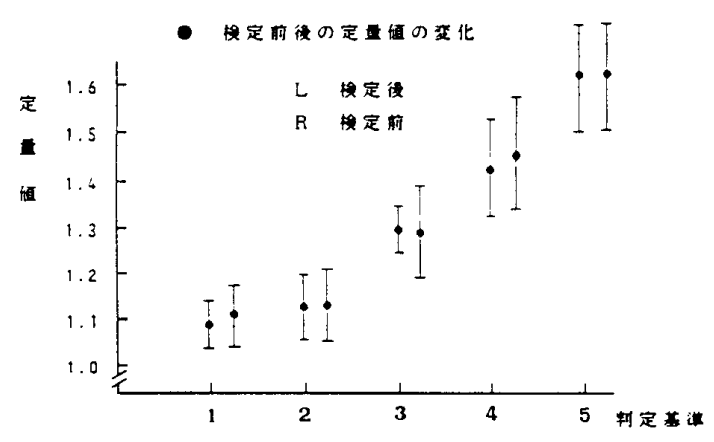

fig 4 